\title{
CORPORATE IDENTITY AS A FACTOR OF CORPORATE SECURITY
}

Elena B. Perelygina

Humanitarian University Ekaterinburg

\begin{abstract}
Forming-up of the corporate identity is based on cognitive, affective and conative elements of corporate culture. The group as an entity choosing goals and values ensures a certain response to standards and values of corporate culture within the parameters of its social responsibility. Corporate security as security of community and cooperation acts as a form of organizational and ethical approach to developing socially responsible attitude of government and business.
\end{abstract}

Keywords: corporate identity, corporate image, responsibility, corporate security.

Regarding the totality of different systems constituting corporate governance, it is recognized that corporate identity is one of the essential attributes that is being given increasing attention by a vast number of entities not only due to their own drive for enhancing of corporate image and improving of corporate governance, but also due to external economic reasons. It has been found that these attributes of companies' development can be assessed and can have value parameters. For example, "having conducted the related survey in 2000, McKinsey \& Company estimated shareholder value at a 50\% discount for Russian companies only due to lack of corporate governance" (The corporate code..., 2002).

Undoubtedly, the above stated reasons impel companies to give serious consideration to forming-up and development of corporate governance and corporate identity. However, companies tend to rely on the strategies, approaches and models offered by foreign authors. Here, "domestic corporations will miss the main point, ignoring the fact that these models were created in communities with more stable political, social and communication environment; in communities that were rigidly structured by professional and local interests; finally, in communities featuring much more monotone and generally valid information... 
By contrast, Russian reality is more volatile, diversified, susceptible to random influences, incorporating longstanding traditions of distrust to straightforward publicity" (Kissinger, 2002).

All the aforesaid factors place an emphasis on the importance of fundamental studies of corporate identity in the context of specifically Russian academic knowledge. Different aspects of corporate identity are analyzed in marketing, PR, etc. However, it does not recall the significance of a corporate identity analysis from the perspective of academic social psychology.

Accordingly, when studying corporate identity, the efforts should be focused on an attempt to "cue" this concept in the context of the present-day social psychology and to develop fundamental hypotheses that explain the nature and functions of corporate identity, providing for empirical verification through an experimental approach.

Many crucial features of corporate identity, which should be addressed individually, are attributed to the diversity of its audience. In imagological literature as well as in management and marketing studies, corporate identity is generally defined as the collective public perception of a company by many people, both externally and internally.

One of the definitions within the described approach states: "The corporate identity is the integrated perception (awareness and evaluation) of a company by different community groups; the perception, which is formed through the information that is kept in their memory and is related to various aspects of the company's activities" (Tomilova, 2002). The definition given by M.V. Tomilova comes to distinguish the descriptive (informative) and evaluative components in corporate identity. It is remarkable that corporate identity, seen as a system of images and evaluations, should appear mostly in management and marketing literature. Indeed, one of the primary management tasks is to fill the description component of corporate identity with information content to establish its positive image in public conscience through positive evaluation of this information. Otherwise, due to certain stereotypes, the information component of corporate identity may turn out to be inconsistent with the company's management objectives. It should be noted that an important role is assigned to interpretation of the corporate identity information component in reliance on relevant attitudes and social expectations (Dontsov \& Yemelianova, 1987). As establishment of positive corporate identity is a concern of any company, it is important to know 
what characteristics it is correlated with. First of all, it is the intensity of emotional response provoked by the image. The slogan "IBM means service", which has been tried and tested for 75 years, highlights a remarkably strong commitment to an individual customer; however, this same concept underpins a distinctive position that the company has in the economic community. "Everybody, from the clerk to the top-level executives, tries to do their best to ensure that the individual customer receives all-encompassing and impressive attention" (Peters \& Waterman, 1995, p. 105).

Certainly, no favorable identity can be established within a short period of time, requiring a certain sequence of actions and processes so that associations, images and perceptions that a customer or a partner forms about the company would have invariably positive connotations. With reference to the IBM Company, it took 75 years to establish its corporate identity, while developing and enhancing it continuously. This implies that not only the time required to create the identity, but also the period of its enduring and economically sustainable existence on the market is an essential component in forming a positive image.

Absolutization of the diversity of the target audience ${ }^{1}$ levels down such a truly important distinction inherent in corporate identity as existence of two components in its structure - the internal image and external image relating to its two fundamentally different audiences. The internal audience is comprised of the company's employees, whereas the external audience includes all other people. In contrast to all other segmentation within the cumulative target audience, the distinction between the internal and external audiences has fundamental significance for understanding of the nature and functions of corporate identity. It is connected, on the one hand, with the specific role that is played by the company's employees constituting its internal audience during creation of the corporate identity. On the other hand, the external image can and must be built with consideration for specific features of the social group, which the image of the company is designed for and targeted at.

It is obvious that moulding of the company image for its positive perception by a specific social group depends on a number of factors that

1 Note that we do not intend to do any special research in terms of sameness or otherness of corporate identity and the image of a company and in this context deem it feasible to rally to the opinion about virtual equality of these concepts. 
must be taken into consideration: kinds and types of activity, social pattern of society, specifics of the perception mechanism and social awareness, specifics of social beliefs, social influence, etc. One of the main elements in forming corporate identity is the task to ensure corporate security.

The Russian theoretical psychology has very few studies addressing corporate security, this can be partially explained by complexity of the phenomenon and an interdisciplinary approach to its analysis. Note that within the developed concept, "corporate" is understood as "common", "united", "uniting". "Corporation (from Late Latin corporatio - forming into a body) 1) association, union, society" (Bol'shoj Rossijskij jenciklopedicheskij slovar', 2007). In the modern Spanish - Russian dictionary the term "corporacion" is translated as "community; unification; corporation; association". In this context, we should point out the importance of corporate identity for the company's corporate security.

As it is noted by E. Fromm, through dynamic adaptation of the personality to social requirements the energy of the person acquires forms that impel him to act in accordance with specific requirements of economy. "The present-day individual does not have to be made to work as hard as he can. Instead of external constraints he has internal need in work $\langle\ldots\rangle$ In other words, instead of submission to the outside authority, the individual created an internal authority - conscience or duty that manage him so effectively as no external authority would ever be able to manage" (Fromm, 2004, p. 15). These very factors determine the principles of formation and maintenance of corporate identity as well as management of social programs of the company.

All the structural and dynamic components of the corporate identity, together with peculiarities of its formation, are taken into consideration in professional management of corporate identity, as present-day objectives of strategic management include management of company perception.

"The growing significance of managing corporate identity is underscored by a 1989 survey in Britain by Market Opinion Research International, which found that 77 percent of the leading industrialists questioned believed that the importance their firms attached to developing and promoting their corporate identity would increase in the near future. Research a year later by CBI and Fitch Consultants corroborated this find- 
ing and the experience of the 1990s strongly suggests that this expectation has materialized" (Corporate Identity Reference for Business...).

Consequently, we can assume the existence of a relationship between the corporate image exposed to the external audience and the internal image of the company. Experimental data available today indicate the existence of similarity between internal and external images of the company. The analysis of internal and external images of the company, which was performed in 2007 (Perelygina, 2007), revealed existence of similar characteristics in company descriptions given by respondents of different groups, which was interpreted as existence of significant invariant elements in the composition of the internal and external images. The above analysis was not intended to find out whether the revealed similarity was a universal quality of the corporate identity and what the reasons for similarity between the internal and external images were.

The readily available answer to the latter question is that the reason for similarity between the internal and external corporate images is the oneness of the displayed. In other words, the internal and external images are similar because both of them are images of the same object - a company, in the same way as the individual image of a person has similar characteristics in perception of different recipients only because it is the image of one and the same person.

However, this answer does not explain the mechanism, through which the singleness of the counter-image generates the singleness of the company image. As a tentative explanation we can offer the following theoretical concept. The objective underlying basis of identity of any company is corporate culture, which in terms of our analysis can be understood as a philosophy, which prevails in the company, determining preferences regarding the ways of attaining the company's aims and explaining the causes of the current condition of the company. The corporate culture includes cognitive, affective and conative elements; thus, corporate culture can be seen as a mix of attitudes shared by members of the company in relation to the company itself, its aims and objectives, content of the performed activity, its external environment, executives and other members of the company.

Adoption of these attitudes by members of the company results in changes in their corporate behavior, i.e. in ways of interaction both with other members of the company and with representatives of its external 
environment, and the above changes reflect essential characteristics of corporate culture.

The positive corporate image means parameters of corporate behavior and corporate culture for new employees. In this context, developing and enhancing of the corporate image is an aspect of the socially responsible behavior both of the executives and of all the participants of corporate behavior.

Should the adherence to principles of corporate culture be seen as entirely formal compliance with internal corporate standards or doe it imply more consistent behavioral and personal changes, including those that are connected with changes in the individual image?

According to our hypothesis, adoption of corporate culture by members of the company results in changes in their individual image and, subsequently, in communication of the corporate image to the external audience (creation of the external image of the company). As it was noted by T.Yu. Basarov, "different cultures differentiate members of one group from another" (Bazarov \& Yeremin, 2002, p. 124).

Here, we interpret an individual image through such concepts as selfconcept, ideal self, self-image displayed to others, and self-image perceived by others, which are defined from the perspective of research related to the self-concept theory, starting from studies by W. James (1991, pp. 97-101) and G. Mead (1934, p. 178), including studies by C. Rogers (1959), R. Burns (1979), I. Kon (1981) et al., as well as studies in strategies of self-presentations (Goffman, 1959; Schlenker, 1980). In other words, self-concept shows how the person sees himself; ideal self is the image of the person he would like to be; self-image perceived by others is how (in his opinion) other people he interacts socially see him; and selfimage displayed to others shows how he would like them to see him. The latter of the elements of the self-awareness structure constitutes the aim the person pursues in development of an individual image. The motivation underlying this development relates to the difference between the self-concept and the ideal self, and, consequently, to the desire to resolve this conflict (Rogers, 1959), as the adoption of the image desirable to the person helps to "pull up" the self-concept to the ideal self.

The process of assimilation and adoption of corporate culture by new members of the company as well as the process of introduction of new corporate culture is best interpreted through the terminology offered by the theory of social learning. For example, adoption of corporate culture 
by newcomers goes mainly through vicarious learning, which A. Bandura refers to the modeling process performing the cue function. Based on the behavior of the adapted members of the company, newcomers acquire symbolic images of the modeled activity, which acts as the prototype for the adequate and inadequate behavior. The compulsory requirement of learning through observation involves identification of typical features of the model behavior and their correct understanding (Bandura, 1986) through verbal explanations and written codes of the company. The significance of these explanations increases in the inverse proportion to the ratio between the number of adapted members of the company and the number of newcomers, reaching the maximum level when new corporate culture is introduced in the company. In this case, it may turn out that the only adaptor of new attitudes and forms of behavior will be the director of the company - the innovator. Thus, it is important, firstly, to verbalize clearly and explain the concept of the new program. Secondly, the director who becomes the only associative model sets a good example. A. Bandura points out that attention to the model depends to a large extent on its personal attractiveness, and the models that possess charismatic qualities are characterized by the highest effectiveness.

The above made assumption is also confirmed by imagology studies. For example, N. Austin and T. Peters in their book published in Cuba, describing the image-focused efforts taken by the CTO of the worldwide renowned company that created Disneyland and is popularizing the experience by opening theme parks all over the world, point out that "in order to resolve a problem he personalized the epitome, the centerpiece, representing this behavior symbolically, straightforwardly, without accessory means, and devoted to this so much time as if these problems affected him personally and had to be solved by him, even though it would take years" (Austin \& Peters, 1987, p. 276). The result of such tactics of the executive officer was that "the famous cleanliness of Disney parks does not depend on high technology; it comes out of the fact that all the employees see cleanliness as their main concern and the company's fame" (Ibid., p. 276). Philipp A. Buari admits that he "was impressed by the president of quite a large metallurgical company, who, in his old grey overall was walking around the workshops at one of his smelters <...> Twenty years later my memory still keeps his conservative and old-fashioned image that stamped in my perception immediately and forever" (Buari, 2001, p. 156). 
Here, interesting findings were received in the research of self-evaluation of the key employees' competence in enhancing of the corporate image of the company ${ }^{2}$. The studies conducted in assessment of personal competence of specialists in industrial management (SIM) and key employees of advertising agencies (KEAA) revealed the following indicators of different types of competence in enhancing of the corporate image of the company: managerial competence (SIM - 22.3\%, KEAA - 60.2\%); theoretical and conceptual competence (SIM - 45.2\%, KEAA - 64.1\%), competence in techniques of corporate image development (SIM - 17.3 $\%$, KEAA - 38\%). At the same time, the overall majority of the respondents (SIM - 68\%, KEAA - 82\%) recognize the importance of vigorous and competent participation in developing and enhancing of the corporate image, admitting the significance of this process for new employees of the organization during their adaptation.

The ready-to-use description codes for required actions can be very effective. These codes are important in assimilation of corporate culture; they embrace the guidelines, slogans, rules, regulations and conduct codes set forth by the top management. Due to the regulatory nature, they foster the adoption of corporate culture, giving straightforward guidelines to members of the company regarding this or that type of behavior. In most cases the observance of the standards is a prerequisite for membership in the organization.

At present, there is an increasing awareness of overall economic, cultural and political interdependence of people, dependence as irreversible consequence of the historic process, which is the backbone of the objective process of increasing the role and significance of ethic principles of social interaction, i.e. evolution of social significance as a mutually positive relationship based on recognizing mutual social responsibility.

In the psychology dictionary, "responsibility" is understood as exercised, represented in different forms, control over the individual's activity in terms of compliance with the established standards and rules. This control can have external forms that ensure the individual is held accountable for his performance (accountability, penalty, etc.) and internal forms of self-regulation of his activity (sense of responsibility, sense

2 Studies were conducted in two groups of specialists in industrial management and employees of advertising agencies, $\mathrm{N}=74$, Ekaterinburg. The statistical data processing was based on the package of application computer programs, Esses.97 and SPSS.10.10. 
of duty). These attitudes are supported by the conceptual statement: "In social psychology the group, along with the personality, is seen as the entity choosing goals and values, solving problems, making decisions, etc." (Andreyeva, Bogomolova, \& Petrovskaya, 2001, p. 162).

The analysis of social responsibility is correlated with understanding of society as the system of connections between social entities, collective and individual, which are self-determined through attitudes to each other. In this context, two main attributive qualities of social responsibility can be pointed out: 1) interdependence of people during collective creation; 2) positive (cooperative) attitude to the partner.

The combination of these attributive qualities of social responsibility suggests existence of mutual responsibility of an individual, society and all its institutions in the process of security assurance. Thus, "every time we must do research, assuming one idea for everything, and we will find this idea. When we grasp it we should look for another two or may be three or even more ideas, and then we should do the same with each of these entities until the initial entity is revealed as qualitatively definite rather than just unified, multiple and indefinite" (Plato, 1971, p. 18).

Here it is feasible to refer to the words of I. Kant: "The only objective division of duties to oneself will be the division into what is formal and what is material in duties to oneself... Both of these duties belong to virtue, either as duties of omission or as duties of commission, but both belong to it as duties of virtue. The first belong to the moral health of a human being as object of both his outer senses and his inner sense, to the preservation of his nature in its perfection (as receptivity); the second belong to his moral prosperity, which consists in possessing a capacity sufficient for all his ends, insofar as this can be acquired; they belong to his cultivation (active perfecting) of himself" (Kant, 1965, p. 355).

We should note that the fundamentals of corporate identity that is developed relying on corporate policy priorities underpinned with the principle of social responsibility correlate with vectors of corporate security within the formats of duty, moral norms and value.

Responsibility has always been referred to a definite entity and reflected the scope of tasks and responsibilities of the individual, i.e. duty limits. "Duty is the individual's obligation to somebody or to his conscience. Conscience, in its turn, is awareness or experience of responsibility based on the self-evaluation of fulfillment of duties" (Korchemnyj, 2005 ). 
When considering duty as the category of corporate security, it should be noted that during his adaptation to social conditions an individual develops such traits of character that stimulate his desire to act in the same manner as he has to act. If personality structure of most people in the company is adapted to objective tasks, which an individual must perform in a given collective, psychological energy of people turns into the productive power required for functioning of this corporate entity.

The theory of subject activity developed by Russian scientists B.G. Ananiev, A.V. Brushlinsky, A.N. Leontiev, S.L. Rubinstein et al. made an important scientific contribution to the conceptual foundation of corporate security as a form of social responsibility. The theory of subject activity argues that the active, reforming and creative individual that is inside the objective reality creates history. Due to this, he makes his life path, consciously or unconsciously. Here, determination is not predetermination; determination is a process, i.e. it is not given ready-to-use initially; on the contrary, it is formed by the individual through self-determination during activity, behavior (Brushlinsky \& Shikhirev, 1998, p. 12). This process determines the vector of development of human resources in corporate entities as related to corporate security assurance.

Implementation of the subject activity relationship determines effectiveness of relationships between the management and the personnel as entities of corporate security. Ages ago Aristotle pointed out the following principles of communication: "For if the ruler is intemperate and unjust, how can he rule well? If the subject, how can he obey well? If he be licentious and cowardly, he will certainly not do his duty. It is evident, therefore, that both of them must have a share of virtue $\langle\ldots\rangle$ Here the very constitution of the soul has shown us the way; in it one part naturally rules, and the other is subject, and the virtue of the ruler we in maintain to be different from that of the subject; the one being the virtue of the rational, and the other of the irrational part $\langle\ldots\rangle$ Hence the ruler ought to have moral virtue in perfection, for his function, taken absolutely, demands a master artificer, and rational principle is such an artificer; the subjects, on the other hand, require only that measure of virtue which is proper to each of them" (Aristotle, 1983). Emphasis on the constructive content of the corporate image - in the format of the internal image constitutes the factor of security regarding violations of the corporate code, information security risk from the part of employees, etc. In the external image format, target, value and activity parameters can act as 
an inducement for proper strategic planning, correlation between the successful image of the company and its adequate activity on the market, analysis of threats from the part of competitors and raiders, etc.

The understanding of social responsibility significance and observance of law as components of the corporate identity permits defining the constructive nature of activity of corporate entities as "responsible security".

In this context, it is worth mentioning the ideas of W. Churchill about creation of the "United States of Europe" that will be able to help to recreate the European family, or as much of it as possible, and to provide it with a structure under which it can dwell in peace (Churchill, 2005, p. 498). Addressing to the state as the entity of social responsibility poses the problem of possible interference of one country in domestic affairs of another country and creates risk of dysfunction of the corporate security system, as the interference of one social entity in internal affairs of another social entity, especially in the form of violence and aggression, is deformation of the principle of social responsibility, thus, causing deformation of moral principles in foreign policy. In these terms, the doctrine of non-interference in domestic affairs of other countries was especially important, being developed on the basis of the Peace Treaty of Westphalia, - solution of problem of violence in relations between countries (Kissinger, 2002, p. 264-265).

H. Kissinger stated pragmatically: "Moral principles are universal and timeless. Foreign policy is bounded by circumstance $\langle\ldots\rangle$ When moral principles are applied without regard to historical conditions, the result is usually an increase in suffering rather than its amelioration. If moral principles are reconciled with internal and international conditions, achievement of the desired goal is restrained due to its contradiction to ideas about national interests" (Ibid., p. 289-290).

As a result, it appears that violation of principles of social responsibility, in fact, means and virtually leads to violation of corporate security fundamentals. H. Kissinger points out that limits of humanitarian interference are defined by the readiness to pay the required price in the form of human and financial losses. The doctrine of interference, which is both universal and limited, can find support only if public community is convinced that the asserted goals are worth this sacrifice. On the one hand, ethical principles establish recognizing an individual as a socially responsible and active entity; on the other hand, political PR promulgate 
priority of national and public interests in interrelationship and interaction with moral principles in foreign policy. As a result, we encounter the task of awareness and comprehensive interpretation of different levels of social responsibility of different levels of social entities in the system of corporate security.

Thus, we can conclude that corporate security represents not only a form of the organizational and ethical approach, but also a system of practical activity aimed at ensuring security in society, i.e. a social function that helps to reinforce the fundamentals of market relations in development of a country and economy, build socially-minded society in the country and to form a coordinated and socially responsible attitudes of government and business to consolidation of legality, protection of private property, assurance of status value and security of business activity, creation of mechanisms of mutual interest in implementation of socially significant projects and fundamentals of international security. These are essential factors for corporate identity of the country, benchmarks of corporate identity of business entities and social responsibility of all entities of corporate security.

\section{References}

Andreyeva, G.M., Bogomolova, N.N., \& Petrovskaya, L.A. (2001). Zarubezhnaja socialnaja psikhologija XX stoletija [Foreign social psychology of the $20^{\text {th }}$ century: Conceptual approaches]. Moscow: Aspect Press.

Aristotle (1983). Sobranie sochinenij [Collected works]: in 4 volumes. Vol. 4. Moscow: Mysl'.

Austin, N., \& Peters, T. (1987). Pasion por la Excelencia: Caracteristicas Diferenciales de las Empresas Lideres. Habana: Edicion Revolucionaria.

Bandura, A. (1986). Social foundations of thought and action: A social cognitive theory. Englewood Cliffs, NJ: Prentice-Hall.

Bazarov, T.Yu., \& Yeremin, B.L. (Eds). (2002). Upravlenie personalom [Personnel management]. $2^{\text {nd }}$ ed., revised and amended. Moscow: YUNITI.

Bol'shoj Rossijskij jenciklopedicheskij slovar' [Big Russian encyclopedic dictionary] (2007). Moscow: Bol'shaja Rossijskaja jenciklopedija [Big Russian encyclopedia].

Brushlinsky, A.V., \& Shikhirev, P.N. (1998). O pol'ze vechnih istin [About value of the eternal verities]. In S. Moskovichi, Mashina, tvorjaschaja bogov [The machine creating gods]. Moscow: Centr psikhologi i psikhoterapii.

Buari, P. (2001). Piar ili strategija [Public relations or strategy]. Moscow: ImageContact consulting group: Infra. 
Burns, R. (1979). The self-concept in theory, measurement and behaviour. New York.

Churchill, W. (2005). Muskuly mira [Sinews of peace]. Moscow: Exmo.

The corporate code accommodates «painful» problems. (2002). Kommersant, April, 26.

Corporate Identity. In Reference for Business. Encyclopedia of Business, $2^{\text {nd }}$ ed. http:// www.referenceforbusiness.com/encyclopedia/Con-Cos/Corporate-Identity.html

Dontsov, A.I., \& Yemelianova, T.P. (1987). Koncepcija social'nyh predstavlenij v sovremennoj francuzskoj psikhologii [Concept of social perceptions in modern French psychology]. Moscow.

Fromm, E. (2004). Imet' ili byt'?; Radi ljubvi k zhizni [To have or to be? ; For the love of life]. Moscow: Iris-Press.

Goffman, E. (1959). The presentation of self in everyday life. New York.

James, W. (1991). Psikhologija [Psychology]. Moscow: Pedagogika.

Kant, I. (1965). Collected works in 6 volumes. Vol. 4, part 2. Moscow: Mysl.'

Kissinger, H. (2002). Nuzhna li Amerike vneshnjaja politika? K diplomatii dlja XXI veka [Does America need a foreign policy? Toward a diplomacy for the $21^{\text {st }}$ century]. Transl., ed. V.L. Inozemtsev. Moscow: Ladomir.

Kolerov, M. (2000). Corporate image: inside and outside. Izvestiya, 27 nov.

Kon, I.S. (1981). Kategorija «Ja» v psikhologii [Category of «self» in psychology]. Psikhologicheskij zhurnal [Journal of psychology], 2(3), 25-38.

Korchemnyj, P.A. (2005). Voennaja psikhologija [Military psychology]. Moscow: OVL.

Mead, G.H. (1934). Mind, Self, and Society. Chicago.

Perelygina, E.B. (2007). Akmeologicheskie osnovanija korporativnogo imidzha: subektno-dejatel'nyj podhod [Acmeological grounds of corporate identity: subject activity approach]. Moscow: APKiPPRO.

Peters, T., \& Waterman, R.H., Jr. (1995). In search of excellence: Lessons from America's Best-Run Companies. London: Harper Collins Business.

Plato (1971). Sobranie sochinenij [Collected works]: in 3 volumes. Vol. 3, part 1. Moscow: Social and economic press.

Rogers, C.R. (1959). A Theory of therapy, personality and interpersonal relationships, as developed in the client-centered framework. In S. Koch (Ed.). Psychology: A study of a science. Vol. 3 (pp. 184-256). New York: McGraw-Hill.

Schlenker, B. (1980). Impression management: The self-concept, social identity and interpersonal relations. Belmont (Calif.).

Tomilova, M.V. (2002). Model of a company image. http: www.cfin.ru/press/ marketing/1998-1/05.shtml dated 24.01.2002. 